\title{
Growth promotion of rice seedlings by fungal and bacterial bioagents effective against bacterial leaf blight of rice
}

\author{
Gokil Prasad Gangwar \\ Department of Plant Pathology, G. B. Pant University of Agriculture and Technology, Pantnagar - 263 145, INDIA \\ E-mail: gokil_prasad@rediffmail.com
}

Received: September 11,2013; Revised received: October 3, 2013; Accepted: 0 ctober 15, 2013

Abstract: In the present investigation, fungal and bacterial bioagents which were effective against pathogen of bacterial leaf blight disease of rice (Xanthomonas oryzae pv. oryzae) was tested for their effect on germination of rice seeds and growth of nursery seedlings under laboratory and glasshouse conditions. Two isolates of fluorescent pseudomonas isolated from rice phylloplane ( $\mathrm{Pf} 83$ and FLP 88), Trichoderma species were isolated from soil of rice field (isolate 40) and Trichoderma harzianum isolated from rice phylloplane. Two commercial formulations (PBA-1 and PBA-2) were tested in the present investigation and compared with chemical treatment $(0.76 \mathrm{~g}$ Emison $+0.18 \mathrm{~g}$ Streptocycline / $\mathrm{kg}$ seeds) and untreated check. Under laboratory conditions, chemical treatment was found most effective in increasing seed germination (43.90\%) followed by Pf 83 and PBA-1 (34.15\%). Bioagent formulations were significantly effective in increase in root and shoot length as compared to check and chemical treatment. Under glasshouse conditions, maximum increase (29.42\%) in seedlings emergence was exhibited by chemical treatment. Maximum increase in root length $(100.15 \%)$ and shoot length $(50.06 \%)$ was recorded with FLP 88 and T. harzianum, respectively. Bioagent formulations also increased fresh and dry root weight over check and chemical treatment. All bioagents formulations were effective over chemical treatment and check in increasing fresh shoot weight. Results of the present study revealed that in the absence of pathogen of bacterial leaf blight of rice, fungal and bacterial bioagents significantly enhanced germination of rice seeds and growth of nursery seedlings.

Keywords: Bacterial leaf blight of rice, Growth promotion, Pseudomonas spp., Rice, Trichoderma harzianum

\section{INTRODUCTION}

Fungal and bacterial bioagents are reported to induce the growth of various crops. These responses may be due to suppression of deleterious root micro-flora including those not causing obvious disease, production of growth stimulating factors (hormones or growth factors) and /or increased nutrient uptake through solubilization and sequestration of nutrients and/or enhanced root growth (Harman, 2000; Mishra and Sinha, 2000; Bailey and Lumsden, 1998). Enhanced root development is also helpful in tolerating the biotic and abiotic stresses by the plants. Spore/cell suspension as well as dry powder has been used to coat the seeds with potential antagonists (Harman et al., 1980; Chao et al., 1986; Mukhopadhyay et al., 1992). Inoculation of seeds, corms, bulbs, tuber, etc. with bioagents prevents seed/ corm decay and seedling blight. This also takes care of seed borne inoculum, particularly externally seed borne and diseases affecting above ground plant parts. For commercial purpose, dry powders of antagonists are used @ 3 to $8 \mathrm{~g}$ powder per $\mathrm{kg}$ seed, based on seed size and formulations of antagonists (Mukhopadhyay et al., 1992; Mukherjee and Mukhopadhyay, 1995; Vidhyasekaran and Muthamilan, 1995). A large number of seed, seedling, root, stem, foliar and panicle diseases have been suppressed by seed treatment with antagonists (Singh et al., 2005). Mukhopadhyay (1996) demonstrated increased growth of several crop plants following seed treatment with $T$. harzianum and $\mathrm{T}$. virens.

Efficacy of fungal and bacterial bioagents against pathogen of bacterial leaf blight disease in rice (Xanthomonas oryzae pv. oryzae) was tested under laboratory (Gangwar and Sinha, 2010a,b), glasshouse (Gangwar and Sinha, 2012a,b) and field conditions (Gangwar, 2012 and Gangwar 2013). In the present study, fungal and bacterial bioagents which were effective against pathogen of bacterial leaf blight disease of rice (Xanthomonas oryzae pv. oryzae) was tested for their effect on germination of rice seeds and growth of nursery seedlings under laboratory and glasshouse conditions.

\section{MATERIALS AND METHODS}

Bioagents for mulations: The experiment was conducted in the Rice Pathology Laboratory and glasshouse of the Department of Plant Pathology, G. B. Pant University of Agriculture and Technology, Pantnagar. Fungal and bacterial bioagents were tested for their effect on germination of rice seeds and growth of nursery seedlings under laboratory and glasshouse conditions. 
Two isolates of fluorescent pseudomonas isolated from rice phylloplane (Pf 83 and FLP 88), Trichoder ma species isolated from soil of rice field (isolate 40) and T. harzianum isolated from rice phylloplane and two commercial formulations viz. PBA-1 (T. harzianum PBAT-43) and PBA-2 (P. fluorescens PBAP-27) were tested in the present investigation and compared with chemical treatment $(0.76$ $\mathrm{g}$ Emison $+0.18 \mathrm{~g}$ Streptocycline $/ \mathrm{kg}$ seeds) and untreated check.

E ffect of bioagents on ger mination of rice seeds, under laboratory conditions: Seeds of susceptible rice cultivar Jaya were soaked in sterilized water for 12 hours. After draining excess water, bioagent formulations $(10 \mathrm{~g} / \mathrm{kg}$ seeds) and chemicals $(0.76 \mathrm{~g}$ Emison $+0.18 \mathrm{~g}$ Streptocycline $/ \mathrm{kg}$ seeds) were applied as seed treatment. Untreated check was also maintained for comparison. On moist double towel paper 25 seeds were placed by maintaining equal distance between seeds and covered with single towel paper. Then towel papers having seeds inside were rolled by covering one side with butter paper and tied with rubber band. These towel papers were incubated in BOD incubator at $28 \pm 1{ }^{\circ} \mathrm{C}$. Data were recorded as germination percent, root length and shoot length at 4,8 and 12 days after treatment application.

E ffect of bioagents on seedling emergence and growth, under glasshouse conditions: Bioagent formulations $\left(10^{6}\right.$ $\mathrm{cfu} / \mathrm{g}) @ 10 \mathrm{~g} / \mathrm{kg}$ seed and chemical treatment $(0.76 \mathrm{~g}$ Emison $+0.18 \mathrm{~g}$ Streptocycline $/ \mathrm{Kg}$ seeds) were applied as seed treatment before sowing of rice seeds in nursery. Rice seed amended with different treatment were than soaked separately in sterilized water for 12 hours. Untreated rice seeds soaked in sterilized water were served as check. Plastic pots were filled $3 / 4$ by height with natural field soil and fertilized with NPK (@ 120:60:40 kg/ ha). Pots were irrigated for puddling. After puddling, 1000 rice seeds from each treatment and check were sown in separate pots. Three replications were maintained for each treatment. Pots were arranged in randomized block design. Regular watering was done by using tap water. Data were recorded as seedling emergence, root and shoot length, fresh and dry root weight and fresh and dry shoot weight after 21 day of treatment application.

Statistical analysis: Statistical analysis of the data obtained from the experiment was done using appropriate programme as per the requirement of the experiment. The critical difference (CD) was calculated at $5 \%$ level of significance for comparison of difference between the means of different treatments.

\section{RESULTS AND DISCUSSION}

$E$ ffect of bioagents on germination of rice seeds, under labor atory conditions: It is revealed by the data presented in Table 1, that all bioagents formulations were significantly effective in increasing percent germination over check, under laboratory conditions. Chemical treatment was most effective which exhibited maximum increase $(43.90 \%)$ in germination. This was followed by Pf 83 and PBA-1, both exhibited increase in germination by 34.15 per cent. All bioagent formulations significantly increased root length as compared to chemical treatment. Maximum increase (73.64\%) in root length was obtained by PBA- 1 followed by Pf $83(65.76 \%)$ and T. harzianum $(60.81 \%)$. All treatments were significantly effective in increasing shoot length over check. FLP 88, Pf 83, PBA1 and T. harzianum showed significantly higher shoot length over chemical treatment. Whereas, PBA-2 and isolate 40 were found to be as effective as chemical treatment in increasing shoot length since the values obtained were not statistically different. Chemical treatment and bioagent formulations may inhibited the growth and/or activities of detrimental microorganisms which may resulted in significantly enhanced seed germination, growth and vigour of rice plant, as compared to check. Similarly, Trichoderma preparations have been reported to increase emergence and vigour of rice (Mishra and Sinha, 2000). Mukhopadhyay (1996) demonstrated increased growth of several crop plants following seed treatment with $T$. harzianum and T. virens.

E ffect of bioagents on seedling emergence and growth, under glasshouse conditions: All bioagent formulations and chemical treatment found statistically effective in increasing percent seed germination over check (Table 2 ), under glasshouse conditions. Maximum increase $(29.42 \%)$ in seedling emergence was exhibited by chemical treatment which was followed by T. harzianum $(22.18 \%)$ and PBA-2 (21.73\%) and Pf 83 (21.73\%). All bioagents were significantly effective in increasing root length over check and chemical treatment. Maximum increase (100.15\%) in root length was recorded with FLP 88 which was followed by PBA-2 (94.64\%) and Pf 83 (89.91\%). All Bioagent formulations were found significantly effective than chemical treatment and check in increasing shoot length. Maximum increase (50.06\%) in shoot length was found with T. harzianum followed by Pf 83 (49.05\%). Similarly, Dubey (1995) reported a significant increase in root and shoot length, fresh and dry weight and yield of main cultivated crops due to seed bacterization with fluorescent pseudomonads. All bioagent formulations were significantly effective in increasing fresh and dry root weight over check and chemical treatment (Table 2). Maximumincrease $(53.22 \%$ ) in fresh root weight exhibited by Pf 83 which was followed by FLP 88 (48.00\%) and PBA$2(44.22 \%)$. Maximumincrease $(58.87 \%)$ in dry root weight was showed by PBA-2 which was followed by Pf 83 ( 54.54 $\%$ ) and FLP 88 (53.67 \%). All bioagent formulation was significantly effective over chemical treatment and check in increasing fresh shoot weight. Pf 83 was most effective bioagent and resulted in maximum increase $(72.85 \%)$ in 

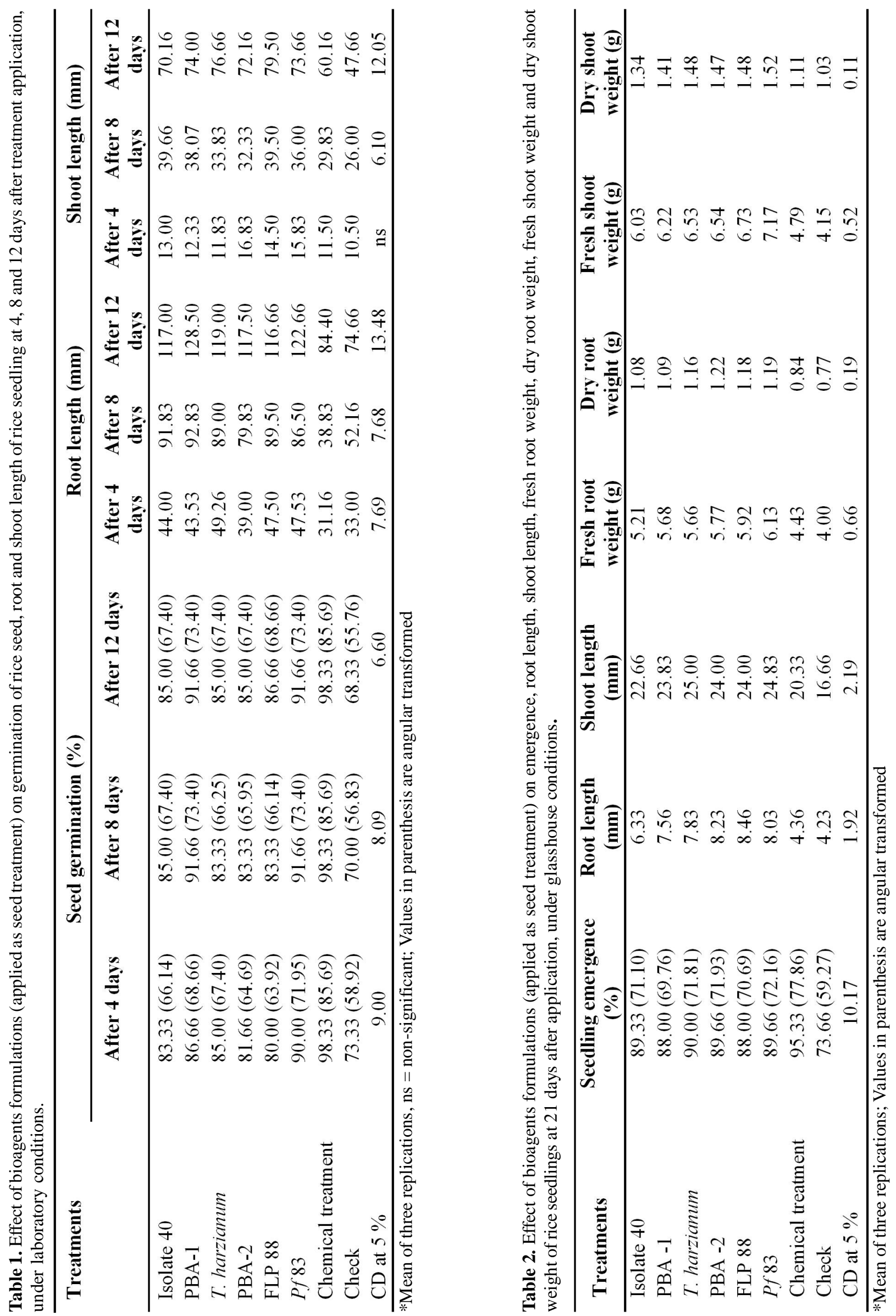
fresh shoot weight which is followed by FLP 88 (62.32\%) and PBA-2 (57.75\%). Maximumincrease (47.89\%) in dry shoot weight was obtained by Pf 83 which is followed by FLP 88 (44.33\%) and T. harzianum (43.68\%). Similarly, Sakthival et al. (1986) and Mishra and Sinha (1998) also reported enhanced growth of rice seedling with bioagent application. Van Peer and Schippers (1988) documented increases in shoot and root fresh weight for tomato, cucumber, lettuce, and potato as a result of bacterization with Pseudomonas strains. Increased fresh and dry weight of shoot, roots and nodules of broad bean was also reported by Yehia et al., 1985 when seeds were coated with $T$. viride. This may be because of production of growth stimulating factors by the bioagents (Windham et al., 1986; Schipper et al., 1987).

The results of the present study depicts that the effect of bioagents on growth and vigour of rice plants was significantly higher than chemical treatment. This exhibits the superiority of bioagents over the chemical treatment. However, in few other cases growth and vigour enhanced by bioagents was significantly higher then check but it was similar or lower then chemical treatments. This may be because of growth promoting effect of bioagents may be ignored because comparatively healthy crops were obtained in conventional rice cultivation. Kloepper et al. (1980) reported that P. fluorescens and other plant growth promoting rhizobacteria enhance plant growth by showing antagonisms to potentially deleterious rhizoplane fungal and bacterial pathogens. The direct application of microorganism to seed or other plant part gives them a competitive advantage over pathogen that must compete for nutrients and sites for attachment prior to infection. Reports are on hand indicating that bacteria may promote plant growth by suppression of deleterious root micro flora indicating those not causing obvious disease (Baker, 1986), altered root growth because of $\mathrm{N}$ production (Baker and Scher, 1987; Voisard et al., 1989), normal effect on plant growth (Imam et al., 1977), hydrogen cyanide ( $\mathrm{HCN}$ ) production (Rangeshwaran and Prasad, 2000), increased root exudation (Prikryl and Vancura, 1980) and induce host resistance (Kempe and Sequeria, 1983).

\section{Conclusion}

In the present study, bioagents formulations were found to be effective in promoting growth of rice plant under laboratory and glasshouse conditions when applied as seed treatment. These bioagent formulations were also effective against bacterial leaf blight disease of rice in previous studies. On the basis of above facts, it can be concluded that these bioagent formulation can also be used under no disease condition which may result in growth promotion of rice plant. Further studies are considered necessary under field conditions.

\section{REFERENCES}

Bailey, B.A. and Lumsden, R.D. (1998). Direct effect of Trichoderma and Gliocladium on plant growth and resistance to pathogens. In : G.E. Harman and C.P. Kubicek (eds.), Trichoderma and Gliocladium Vol. 2. Taylor and Francis, London, pp. 185-204.

Baker, R. (1986). Biological control: an overview. Can.J . PI. Path., 8: 218-221.

Baker, R. and Scher, F.M. (1987). Enhancing the activity of biological control agents. In Chet, I. (ed.), Innovative Approaches to Plant Disease Control. Wiley Intersci. New York, U.S.A. pp. 1-18.

Chao, W.L., Nelson, F.B., Harman, G.E., and Hoch, H.C. (1986). Colonization of the rhizosphere by biological control agents applied to seeds. Phytopathol., 76: 60-65.

Dubey, S.C. (1995). Evaluation of fungal antagonistic against Thanatephorus cucumeris causing banded blight of rice. Paper presented at the first International symposium on Rhizoctonia, ISR'95 at Leeuwenhorst Congress Centrum Noordwijkerhout, Netherland. pp. 27-30.

Gangwar, G.P. (2012). Efficacy of commercial formulations of bioagent against bacterial leaf blight of rice. Ann. PI. Protec. Sci., 20(2): 389-391.

Gangwar, G.P. (2013). Efficacy of different isolates of fluorescent pseudomonads against bacterial leaf blight of rice. Afr. J . Agric. Res., 8(37): 4588-4591.

Gangwar, G.P. and Sinha, A.P. (2010a). Comparative antagonistic potential of Trichoderma spp. against Xanthomonas oryzae pv. oryzae. Ann. PI. Protec. Sci., 18: 458-463.

Gangwar, G.P. and Sinha, A.P. (2010b). Evaluation of fluorescent pseudomonads against $X$ anthomonas oryzae $p v$. or yzae causing bacterial leaf blight of rice. Ann. PI. Protec., Sci. 18: 532-534.

Gangwar, G.P. and Sinha, A.P. (2012a). Comparative antagonistic potential of fungal and bacterial bioagents against isolates of Xanthomonas oryzae pv. oryzae. Ann. PI. Protec. Sci., 20: 154-159.

Gangwar, G.P. and Sinha, A.P. (2012b). Evaluation of Trichoderma spp. and fluorescent pseudomonads for the management of bacterial leaf blight of rice. Indian Phytopath., 65(1): 89-91.

Harman, G.E. (2000). Myths and dogmas of Biocontrol: Changes in the perceptions derived from research on Trichoderma harzianum T-22. Plant Dis., 84: 377-393.

Harman, G.E., Chet, I. and Baker, R. (1980). Trichoderma hamatum effects on seed and seedling disease induced in radish and pea by Pythium spp. and Rhizoctonia solani. Phytopathol., 70: 1167-1172.

Imam, M.K., Badawy, F.H. and El-Hudairy, A. (1977). Response of tomato and two other vegetable crops to inoculation with Azotobacter. The Libyan J. Agric., 6: 156-167.

Kempe, J. and Sequeira, L. (1983). Biological control of bacterial wilt of potatoes, attempts to induce resistance by treating tubers with bacteria. Plant D is., 67: 499-503.

Kloepper, J.W., Schroth, M.N. and Miller, T.D. (1980). Effects of rhizosphere colonization by plant growth promoting rhizobacteria on potato plant development and yield. Phytopathol., 70: 1078-1082. 
Mishra, D.S. and Sinha, A.P. (1998). Plant growth promotion by some biocontrol agents. In: Fiftieth Annual Meeting of Indian Phytopathological Society and National Symposium on "Present Scenario in D iseases of Oilseeds and Pulses" held at Aurangabad, Maharastra, India. (Abstr.).

Mishra, D.S. and Sinha, A.P. (2000). Plant growth-promoting activity of some fungal and bacterial agents on rice seed germination and seedling growth. Trop. Agric., 77: 188-191.

Mukherjee, P.K. and Mukhopadhyay, A.N. (1995). In situ mycoparasitism of $\mathrm{G}$ liocladium virens on Rhizoctonia solani. Indian Phytopath., 48: 101-102.

Mukhopadhyay, A.N. (1996). Recent innovations in plant disease control by ecofriendly biopesticides. In Presidential address, Agriculture Science section, $83^{\text {th }}$ Indian Science Congress, Patiala, India.

Mukhopadhyay, A.N., Shrestha, S.M. and Mukherjee, P.K (1992.). Biological seed treatments for control of soil borne plant pathogens. FAO Plant Prot. B ull., 40: 1-10.

Prikryl, Z. and Vancura, V. (1980). Root exudates of plants IV. wheat root exudation as dependent on growth concentration gradient of exudates and the presence of bacteria. Plant and Soil, 57: 69-83.

Rangeshwaran, R. and Prasad, R.D. (2000). Isolation and evaluation of rhizospheric bacteria for biological control of chickpea wilt pathogen. J. Biol. Control., 14: 9-15.

Sakthival, N., Sivamani, E., Unnamalai N. and Gnanamanickam, S.S. (1986). Plant growth-promoting rhizobacteria in enhancing plant growth and suppressing plant pathogens. Curr. Sci., 55(1): 22-25.
Schipper, B., Baker, A.W. and Baker, P.A.H.M. (1987) Interactions of deleterious and beneficial rhizosphere microorganisms and the effect of cropping practice. Ann. Rev. Phytopath., 25: 339-358.

Singh, U.S., Mishra, D.S., Zaidi, N.W., Varshney, S., Sharma, R. and Singh, N. (2005). Potential and effectiveness of fungi and bacteria as biocontrol agents for plant disease management. In Integrated pest management: principles and application Volume 1: Principles (Singh, A., Sharma, O.P. and Garg, D.K. ed.), CBS, New Delhi, India.

Van Peer, R., and Schippers, B. (1988). Plant growth responses to bacterization with selected Pseudomonas spp. strains and rhizosphere microbial development in hydroponic cultures. Can. J. Microbiol., 35: 456-463.

Vidhyasekaran, P. and Muthamilan, M. (1995). Development of formulations of Pseudomonas fluorescens for control of chickpea wilt. Plant Dis., 79: 782-786.

Voisard, C., Keel, C., Hars, D. and Defago, G. (1989). Cyanide production by Pseudomonas fluorescens helps suppress black root rot of tobacco under genotobiotic conditions. EMBO J , 8: 351-358.

Windham, M.T., Elad, Y. and Baker, R. (1986). A mechanism for increased plant growth induced by Trichoderma spp. Phytopathology, 76: 518-521.

Yehia, A.H., EI-Hassan, S. A. and EI-Bahadli, A.H. (1985). Biological seed treatment to control Fusarium root rot of broad bean. Egyptian. J . Phytopathol., 14:59-66. 